$\begin{array}{ll}\text { Abstracta Iranica } & \begin{array}{l}\text { Abstracta Iranica } \\ \text { Revue bibliographique pour le domaine irano-aryen }\end{array} \\ & \text { Volume } 25 \mid \mathbf{2 0 0 4} \\ \text { Comptes rendus des publications de } 2002\end{array}$

«Recent Khotanese ghostwords ». BAI, n.s., 13
(1999 [2002]), pp. 151-155.

Mauro Maggi

(2) OpenEdition

Journals

Édition électronique

URL : http://journals.openedition.org/abstractairanica/4130

ISSN : 1961-960X

Éditeur :

CNRS (UMR 7528 Mondes iraniens et indiens), Éditions de l'IFRI

Édition imprimée

Date de publication : 15 mai 2004

ISSN : 0240-8910

Référence électronique

Mauro Maggi, « «Recent Khotanese ghostwords ». BAl, n.s., 13 (1999 [2002]), pp. 151-155. », Abstracta

Iranica [En ligne], Volume 25 | 2004, document 29, mis en ligne le 15 mars 2006, consulté le 25

septembre 2020. URL : http://journals.openedition.org/abstractairanica/4130

Ce document a été généré automatiquement le 25 septembre 2020.

Tous droits réservés 


\section{« Recent Khotanese ghostwords ». BAI, n.s., 13 (1999 [2002]), pp. 151-155.}

Mauro Maggi

1 The author discusses the readings and etymologies of seven words, mostly from the St. Petersburg manuscripts of the Old Khotanese Suvarnabhāsottamasūtra (Suv) studied by R. E. Emmerick (cf. Abs. Ir. 17-19 (1994-1996), c.r. $n^{\circ}$ 541) : (1) the proper name Suv 14.24 janiș̣ei (not jatīṣei), Sanskrit jinarșabhah, is from a Prakrit form *janeșava- ; (2) Suv 11.10 jsauca- (not jsaica-) 'boy' and jsicā- 'girl' are plausibly derived from *jafta-ča and * jafti-čci- and provided with Sogdien and Kh. cognates; (3) because of its -t-, the gen.-dat. sg. Suv 17.8 mäjṣäte 'wife' (unpubl.) is tentatively assigned to a stem *mäjṣäti<*miždUšsati- (sic), but this is doubtful: Sims-Williams' *mäjṣaï- <*miždušaki- accounts more plausibly for the attested forms. (4) Suv 10.47 nvāna (not kvāna) is derived from *ni-pādana- and translated 'bed'; (5) Sims-Williams' emendation *gvāska-masi ( ${ }^{*} U{ }^{*}$ $b \overline{a z u}(-k a)$ 'fathom') for the problematic Suv 4.12 nvāska-masi is rejected and a possible meaning 'within shouting distance' (cf. nvāsa- 'noise') is suggested ; (6) the reading Suv 6.4.11 pabuyāmate 'fragrances' is confirmed by an unpublished fragment; (7) in Suv 2.16, 17 uscäke < *us-či-k-kā- or better *us-čai - $a k \bar{a}$ - 'something piled up (to sit on)' must be read instead of usdäke $<^{*} u s$-sadikā-.

\section{INDEX}

Thèmes : 2.1. Langues anciennes 


\section{AUTEURS}

MAURO MAGGI

Istituto Universitario Orientale - Naples 